\title{
Makalah \\ Pentingnya Pendidik dan Tenaga Kependidikan dalam Proses pembelajaran
}

Diajukan untuk memenuhi nilai Ujian tengah semester mata kukiah manajemen peserta didik.

Dosen pengampu : Wahyu Bagja Sulfemi, M.Pd

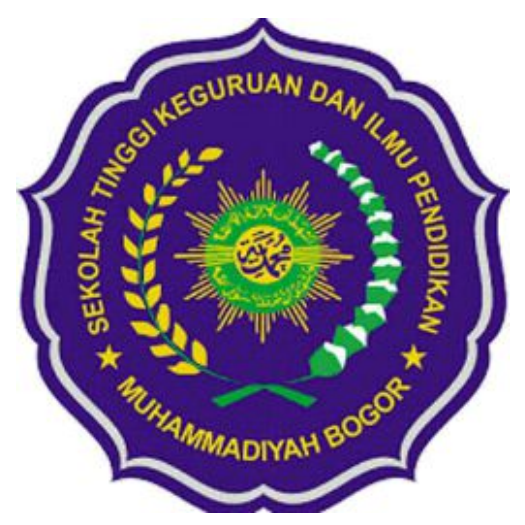

Disusun Oleh

Maulana Sopian (0142S1A018017)

PROGRAM STUDI ADMINISTRASI PENDIDIKAN STKIP MUHAMMADIYAHBOGOR 2019 


\section{KATA PENGANTAR}

Segala puji bagi Allah SWT yang telah memberikan kami kemudahan sehingga kami dapat menyelesaikan makalah ini dengan tepat waktu. Tanpa pertolongan-Nya tentunya kami tidak akan sanggup untuk menyelesaikan makalah ini dengan baik. Shalawat serta salam semoga terlimpah curahkan kepada baginda tercinta kita yaitu Nabi Muhammad SAW yang kita nanti-natikan syafa' atnya di akhirat nanti.

Penulis mengucapkan syukur kepada Allah SWT atas limpahan nikmat sehat-Nya, baik itu berupa sehat fisik maupun akal pikiran, sehingga penulis mampu untuk menyelesaikan pembuatan makalah ini.

Penulis tentu menyadari bahwa makalah ini masih jauh dari kata sempurna dan masih banyak terdapat kesalahan serta kekurangan di dalamnya. Untuk itu, penulis mengharapkan kritik serta saran dari pembaca untuk makalah ini, supaya makalah ini nantinya dapat menjadi makalah yang lebih baik lagi. Kemudian apabila terdapat banyak kesalahan pada makalah ini penulis mohon maaf yang sebesarbesarnya.

Demikian, semoga makalah ini dapat bermanfaat. Terima kasih.

Leuwiliang, 26 November 2019

Penulis 


\section{Daftar Isi}

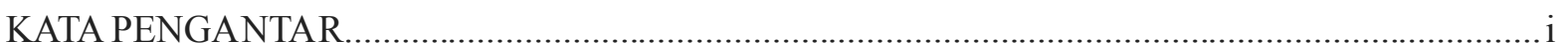

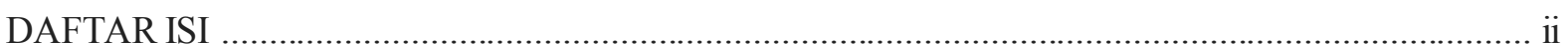

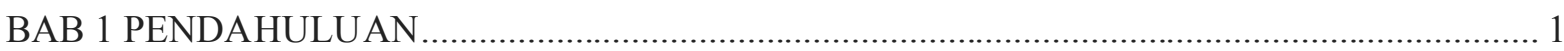

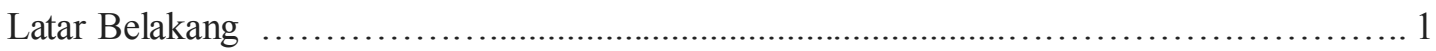

Rumusan Masalah .............................................................................. 1

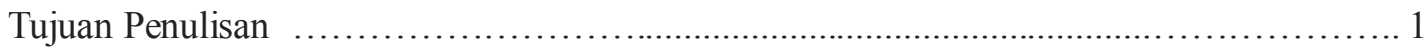

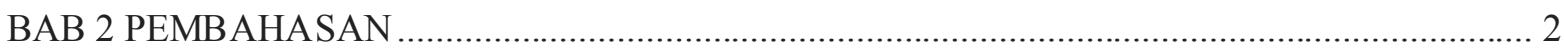

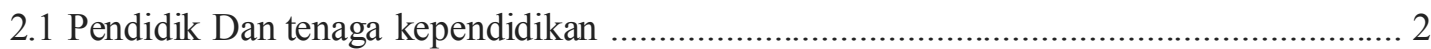

2.2 Kompetensi dan kualifikasi pendidik dan tenaga kependidikan.................................... 5

2.3 Peran Pendidik dan Tenaga kependidikan..................................................................... 9

BAB 3 PENUTUP

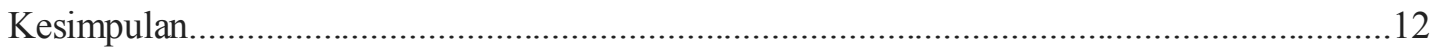

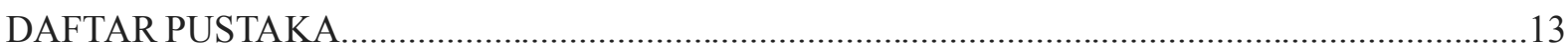




\section{BAB 1}

\section{PENDAHULUAN}

\section{LATAR BELAKANG}

Pendidik dan tenaga kependidikan merupakan salah satu dari Standar Nasional Pendidikan yang memerlukan perhatian khusus dari pemerintah dan masyarakat. Pandangan penting terhadap pendidik sebagai berikut.

1) Guru yang diharapkan masa kini;

2) Tugas guru sebagai panggilan hidup;

3) Guru yang demokratis;

4) Guru yang professional;

5) Peningkatan kualitas guru. Mengenai tenaga kependidikan diperlukan adanya pencerahan, pencerahan tersebut dapat dilaksanakan melalui pendekatan sumber daya manusia, antara lain meliputi : 1) kompetensi, (2) sertifikasi, (3) kualifikasi, (4) rekrutmen dan seleksi, (5) pengembangan karier, (6) penilaian kinerja, (7) penghargaan dan perlindungan, dan (8) pemberhentian. Selanjutnya, tulisan ini juga menyoroti pendidik dan tenaga kependidikan dari segi poleksosbud.

Rumusan Masalah

1. Apa yang di maksud Pendidik Dan Tenaga Kependidikan?

2. Apa kompetensi yang harus di miliki oleh seorang Pendidik Dan Tenaga Kependidikan?

3. Apa peran penting Seorang Pendidik dan Tenaga Kependidikan?

Tujuan Penulisan

1. Mengetahui definisi tentang pendidik dan Tenaga kependidikan.

2. Mengetahui kompetensi apa yang harus di miliki oleh seorang pendidik dan tenaga kependidikan.

3. Mengetahui peran penting seorang pendidik dan tenaga kependidikan 


\section{BAB 2}

\section{PEMBAHASAN}

\subsection{PENDIDIK DAN TENAGA KEPENDIDIKAN}

Pasal 39 UU No. 20 tahun 2003 tentang Sisdiknas, yang menyatakan bahwa (1) Tenaga kependidikan bertugas melaksanakan administrasi, pengelolaan, pengembangan, pengawasan, dan pelayanan teknis untuk menunjang proses pendidikan pada satuan pendidikan, dan (2) Pendidik merupakan tenaga profesional yang bertugas merencanakan dan melaksanakan proses pembelajaran, menilai hasil pembelajaran, melakukan pembimbingan dan pelatihan, serta melakukan penelitian dan pengabdian kepada masyarakat, terutama bagi pendidikypadayperguruanytinggi.

Pengelolaan pendidikan berasal dari kata manajemen, sedangkan istilah manajemen sama artinya dengan administrasi. Dapat diartikan pengelolaan pendidikan sebagai supaya untuk menerapkan kaidah-kaidah adiministrasi dalam bidang pendidikan.

Pengertian Pendidik:

Dari segi bahasa,pendidik adalah orang yang memberi pendidikan (pengajar). Sehingga pendidikan adalah orang yang melakukan kegiatan dalam bidang mendidik. Kata tersebut mengacu kepada kata pendidik, karena kata itu mengarah kepada seseorang yang memberikan pengetahuan, ketrampilan, atau pengalaman kepada orang lain.

Adapun pengertian pendidik menurut istilah telah banyak dirumuskan oleh para ahli pendidikan, menurut Sutari Imam Barnadib pendidik adalah orang yang dengan sengaja mempengruhi orang lain untuk mencapai kedewasaan, lain halnya menurut Ahmad Tafsir menyatakan bahwa pendidik adalah siapa saja yang bertanggung jawab terhadap perkembangan peserta didik. Maka secara umum pendidik Ialah orang yang memikul pertanggung jawaban untuk mendidik, sedangkan secara khusus pendidik dalam perspektif islam adalah orang-orang yang bertanggung jawab terhadap perkembangan peserta didik, baik potensi kognitif, afektif maupun psikomotorik yang sesuai dengan nilai-nilai ajaran islam.

Dengan demikian pendidik dapat di pahami sebagai orang yang bertanggung jawab terhadap upaya perkembangan jasmani dan rohani peserta didik agar mencapai tingkat kedewasaan sehingga mampu menunaikan tugas-tugas kemanusiaanya sesuai dengan nilainilai ajaran islam. Oleh karena itu, pendidik dalam hal ini tidak hanya sebatas pada orangorang yang bertugas di sekolah saja, tetapi setiap orang yang terlibat dalam proses pendidikan anak mulai sejak kandungan hingga dewasa, bahkan sampai meninggal dunia. Adapun pendidik dalam kaitannya dengan pendidikan terhadap orang lain pada garis besarnya dapat di kategorikan ke dalam orang tua, guru dan masyarakat.

1. Orang Tua 
Orang tua merupakan pendidik yang utama dan pertama bagi seorang anak. Karena dari merekalah anak mula-mula menerima pendidikan. Di dalam lingkungan keluarga dalampertumbuhan psikis dan fisiknya sangat membutuhkan bimbingan dari orang tua.

\section{Guru}

Sejalan dengan tuntutan kebutuhan manusia dan pekerjaan, maka orang tua tidak bisa bertanggung jawab sepenihnya terhadap pendidikan anak. Karena itulah orang tua melimpahkan sebagian tanggung jawabnya kepada orang lain, dalam hal ini adalah guru.

\section{Masyarakat}

Masyarakat turut serta dalam memikul tanggungjawab pendidikan. Karena itulah pendidikan dalam Islam merupakan tanggung jawab bersama dengan setiap anggota masyarakat, bukan tanggung jawab individu tertentu. Sebab, masyarakat adalah kumpulankumpulan individu yang menjalin satu kesatuan. ${ }^{1}$

\section{Pengertian Tenaga Kependidikan:}

Tenaga Kependidikan adalah anggota masyarakat yang mengabdikan diri dan diangkat untuk menunjang Penyelenggaraan Pendidikan. Yang termasuk ke dalam tenaga kependidikan adalah: kepala satuan pendidikan; pendidik; dan tenaga kependidikan lainnya.

Kepala Satuan Pendidikan yaitu orang yang diberi wewenang dan tanggung jawab untuk memimpin satuan pendidikan tersebut. Kepala Satuan Pendidikan harus mampu melaksanakan peran dan tugasnya sebagai edukator, manajer, administrator, supervisor, leader, inovator, motivator, figur dan mediator (Emaslim-FM) Istilah lain untuk Kepala Satuan Pendidikan adalah: Kepala Sekolah, Rektor, Direktur, serta istilah lainnya. Sedangkan pendidik atau di Indonesia lebih dikenal dengan pengajar, adalah tenaga kependidikan yang berpartisipasi dalam menyelenggarakan pendidikan dengan tugas khusus sebagai profesi pendidik. Pendidik mempunyai sebutan lain sesuai kekhususannya yaitu: Guru, Dosen, Konselor, Pamong belajar, widyaiswara, tutor, instruktur, fasilitator, Ustadz, dan sebutan lainnya.

Tenaga Kependidikan lainnya ialah orang yang berpartisipasi dalam penyelenggaraan pendidikan di satuan pendidikan, walaupun secara tidak langsung terlibat dalam proses pendidikan, diantaranya:

a. Wakil-wakil/ Kepala urusan umumnya pendidik yang mempunyai tugas tambahan dalam bidang yang khusus, untuk membantu Kepala Satuan Pendidikan dalam penyelenggaraan pendidikan pada institusi tersebut. Contoh: Kepala Urusan Kurikuhum .

b. Tata usaha, adalah Tenaga Kependidikan yang bertugas dalam bidang administrasi instansi tersebut. Bidang administrasi yang dikelola diantaranya; Administrasi surat menyurat dan pengarsipan, Administrasi Kepegawaian, Administrasi Peserta Didik, Administrasi Keuangan, Administrasi Inventaris dan lain-lain. 
c. Laboran, adalah petugas khusus yang bertanggung jawab terhadap alat dan bahan di Laboratorium.

Seperti yang sudah di jelaskan di atas bahwasannya perlunya dibedakan antara pendidik dengan tenaga kependidikan. Guru jelas adalah pendidik. Di dalam Rancangan Peraturan Pemerintah (RPP) BAB XII, Tahun2005 Pasal 139, Pasal 1 dinyatakan bahwa pendidik mencakup guru, dosen, konselor, pamong belajar, pamong widyaiswara, tutor, instruktur, fasilitator, pelatih, dan sebutan lain dari profesi yang berfungsi sebagai agen pembelajaran peserta didik. Di dalam Peraturan Pemerintah Nomor 19 Tahun 2005 Tentang Standar Nasional Pendidikan, Bab VI, pasal 28 dinyatakan bahwa Kompetensi sebagai agen pembelajaran pada jenjang pendidikan dasar dan menengah serta pendidikan anak usia dini meliputi, kompetensi: pedagogik, kepribadian, profesional, dan sosial. Selanjutnya, di dalam Pasal 2 dinyatakan bahwa pendidik mempunyai tugas dan tanggung jawab sebagai berikut.

a. Guru bertugas dan bertanggung jawab sebagai agen pembelajaran yang memotivasi , memfasilitasi, mendidik,membimbing, dan melatih peserta didik sehingga menjadi manusia berkualitas yang mengaktualisasikan potensi kemanusiaannya secara optimum, pada jalur pendidikan formal jenjang pendidikan dasar dan menengah termasuk pendidikan anak usia dini formal.

b. Dosen bertugas dan bertanggung jawab sebagai agen pembelajaran yang memotivasi, memfasilitasi, mendidik, membimbing,dan melatih peserta didik pada jenjang pendidikan tinggi sehingga menjadi manusia berkualitas yang mengaktualisasikan potensi kemanusiaannya secara optimum, melakukan penelitian untuk pengembangan ilmu, teknologi, dan/atau seni (IPTEKS), serta melakukan pengabdian kepada masyarakat.

c. Konselor bertugas dan bertanggung jawab memberikan layanan bimbingan dan konseling kepada peserta didik di satuan pendidikan pada jenjang pendidikan dasar, menengah, dan tinggi.

d. Pamong belajar bertugas dan bertanggung jawab menyuluh, mengajar, membimbing, melatih peserta didik, dan mengembangkan: model program pembelajaran, alat pembelajaran, dan pengelolaan pembelajaran pada jalur pendidikan nonformal.

e. Pamong bertugas dan bertanggung jawab membimbing dan melatih anak usia dini pada kelompok bermain, penitipan anak dan bentuk lain yang sejenis.

f. Widyaiswara bertugas dan bertanggung jawab mendidik, mengajar dan melatih peserta didik pada program pendidikan dan pelatihan prajabatan dan/ atau Pemerintah Daerah.

g. Tutor bertugas dan bertanggung jawab memberikan bantuan belajar kepada apeserta didik dalam proses pembelajaran mandiri atau proses pembelajaran dalam kelompok pada satuan pendidikan jalur formal dan nonformal.

h. Instruktur bertugas dan bertanggung jawab memberikan pelatihan teknis kepada peserta didik pada kursus dan/ atau pelatihan. 
i. Fasilitator bertugas dan bertanggung jawab memberikan pelayanan pembelajaran pada lembaga pendidikan dan pelatihan.

j. Pelatih bertugas dan bertangggung jawab memberikan pelatihan teknis olah raga kepada peserta didik pada kegiatan pelatihan, pada satuan pendidikan jalur formal atau nonformal.(Nur, H:2009)

Adapun, mengenai tenaga kependidikan dinyatakan di dalam Pasal 140 Ayat 1 (RPP, Bab XII/2005) sebagai berikut.

Tenaga kependidikan mencakup pimpinan satuan pendidikan, penilik satuan pendidikan nonformal, pengawas satuan pendidikan formal, tenaga perpustakaan, tenaga laboratorium, teknisi sumber belajar, tenaga lapangan pendidikan, tenaga administrasi, psokolog, pekerja sosial, terapis, tenaga kebersihan sekolah, dan sebutan lain untuk petugas sejenis yang bekerja pada satuan pendidikan. Tugas dan tanggung jawab tenaga kependidikan di dalam ayat 2 (Pasal 140/Bab XII/RPP/2005) sebagai berikut.

a. Pimpinan satuan pendidikan bertugas dan bertanggung jawab mengelola satuan pendidikan pada pendidikan formal dan/ atau nonformal.

b. Penilik bertugas dan bertanggung jawab melakukan pemantauan,penilaian, dan pembinaan pada satuan pendidikan nonformal.

c. Pengawas bertugas dan bertanggung jawab melakukan pemantauan, penilaian, dan pembinaan pada satuan pendidikan dasar, pendidikan menengah, dan pendidikan anak usia dini jalur formal.

d. Tenaga perpustakaan bertugas dan bertanggung jawab melaksanakan pengelolaan sumber belajar di perpustakaan.

e. Tenaga laboratorium bertugas dan bertanggung jawab membantu pendidik mengelola kegiatan praktikum di laboratorium satuan pendidikan.

f. Teknisi sumber belajar bertugas dan bertanggung jawab mempersiapkan, merawat, memperbaiki sarana dan prasarana pembelajaran pada satuan pendidikan.

g. Tenaga lapangan pendidikan bertugas dan bertanggung jawab melakukan pendataan, pemantauan, pembimbingan, (Nur, H:2009)

\subsection{KOMPETENSI DAN KUALIFIKASI PENDIDIK DAN TENAGA KEPENDIDIKAN.}

Kompetensi diartikan sebagai suatu hal yang menggambarkan kualifikasi atau kemampuan seseorang, baik yang kualitatif maupun kuantitatif. Kompetensi didefinisikan sebagai kewenangan (memutuskan sesuatu). Ada juga yang mengatakan bahwa

"kompetensi atau secara umum diartikan sebagai kemampuan dapat bersifat mental maupun fisik." 
Sesuai dengan Undang-Undang Peraturan Pemerintah. No14 tahun 2005 pada pasal 8 mengatakan tentang kompetensi seorang guru. Ada 4 kompetensi dasar yang harus dimiliki oleh seorang guru, antara lain: kompetensi kepribadian, kompetensi pedagogik, kompetensi professional, dan kompetensi sosial. (Sulfemi, 2015)

Dan dalam UU guru dan dosen dalam BAB II (kompetensi dan sertifikasi) pasal 2 "guru wajib memilki kualifikasi akademik, kompetensi, sertifikasi pendidik, sehat jasmani dan rohani, serta memiliki kemampuan untuk mewujudkan tujuan pendidikan nasional. Dan dijelaskan dalam pasal 3 ayat 2 kompetensi guru sebagai mana yang dimaksud meliputi kompetensi pedagogik, kompetensi kepribadian, kompetensi sosial, dan kompetensi professional yang diperoleh melalui pendidikan profesi.(Undang-Undang Guru dan Dosen, 2011 : 65).Dalam penjabaran lain ke-4 kompetensi guru di atas dijabarkan sebagai berikut:

\section{Kompetensi Pedagogik}

Kompetensi pedagogik merupakan kemampuan dalam mengelola pembelajaran peserta didik, yang meliputi: a) pemahaman peserta didik, b) perancang dan pelaksanaan pembelajaran, c) evaluasi pembelajaran dan, d) pengembangan peserta didik untuk mengaktualisasi berbagai potensi yang dimilikinya.Kompetensi pedagogik yaitu kemampuan seorang guru dalam mengelola proses pembelajaran peserta didik.

Selain itu kemampuan pedagogik juga ditunjukkan dalam membantu, membimbing dan memimpin peserta didik.

Berdasarkan pengertian seperti tersebut di atas maka yang dimaksud dengan pedagogik adalah ilmu tentang pendidikan anak yang ruang lingkupnya terbatas pada interaksi edukatif antara pendidik dengan siswa. Dapat pula diartikankompetensi pedagaogik adalah sejumlah kemampuan guru yang berkaitan dengan ilmu dan seni mengajar siswa.

Dengan Demikian, kompetensi pedagogik maka guru mempunyai kemampuankemampuan sebagai berikut

1) Mengaktualisasikan landasan mengajar,

2) Pemahaman terhadap peserta didik,

3) Menguasai ilmu mengajar (didaktik metodik),

4) Menguasai teori motivasi,

5) Mengenali lingkungan masyarakat,

6) Menguasai penyusunan kurikulum,

7) Menguasai teknik penyusunan RPP,

8) Menguasai pengetahuan evaluasi pembelajaran, dan lain-lain. (Sulfemi:2015)

Dalam UU guru dan dosen, kompetensi pedagogik sebagaimana yang dimaksud pada ayat 2 merupakan kemampuan guru dalam pengelolaan pembelajaran peserta didik yang sekurang-kurangnya meliputi:

1) Pemahaman wawasan atau landasan kependidikan, 
2) Pemahaman terhadap peserta didik,

3) Pengembangan kurikulum atau silabus,

4) Perancangan pembelajaran,

5) Pelaksanaan pembelajaran yang mendidik dan dialogis,

6) Pemanfaatan teknologi pembelajaran,

7) Evaluasi hasil belajar, dan

8) Pengembangan peserta didik untuk mengaktualisasikan berbagai potensi yang di milikinya. (Undang-Undang Guru dan Dosen, 2011 : 66)

Menurut Permendiknas nomor 16 tahun 2007 pedagogik guru mata pelajaran terdiri atas 37 buah kompetensi yang di rangkum dalam 10 kompetensi inti seperti disajikan berikut;

1) Menguasai peserta didik dari aspek fisik, moral, spiritual, sosial, kultural, emosional, dan intelektual.

2) Menguasai teori belajar dan prinsip-rinsip pembelajaran yang mendidik.

3) Mengembangkan kurikulum yang terkait dengan mata pelajaran yang diampu.

4) Menyelenggarakan pembelajaran yang mendidik.

5) Memanfaatkan teknologi informasi dan komunikasi untuk kepentingan pembelajaran.

6) Memfasilitasi pengembangan potensi peserta didik untuk mengaktualisasikan berbagai pontensi yang dimiliki.

7) Berkomunikasi secara efektif, empatik, dan santun dengan peserta didik.

8) Menyelenggarakan penilaian dan evaluasi proses dan hasil belajar.

9) Memanfaatkan hasil penilaian dan evaluasi untuk kepentingan pembelajaran.

10) Melakukan tindakan reflektif untuk peningkatan kualitas pembelajaran.(Sulfemi:2015)

Jadi, dari keseluruhan pengertian tadi dapat kami simpulkan bahwa kompetensi pedagogik adalah cara guru dalam mengajar dan mengatur sistem pembelajaran di kelas dengan menjalin interaksi yang baik terhadap peserta didik.

2. Kompetensi Kepribadian

Kompetensi kepribadian adalah kompetensi yang berkaitan dengan perilaku pribadi guru itu sendiri yang kelak harus memiliki nilai-nilai luhur sehingga terpancar dalam perilaku 
sehari-hari.(Roqib dan Nurfuadi, 2009 :122). kompetensi Personal, artinya sikap kepribadian yang mantap sehingga mampu menjadi sumber intensifikasi bagi subjek.

\section{Kompetensi Sosial}

Dimaksud dengan kompetensi sosial di dalam Peraturan Pemerintah Nomor 19 tahun 2005 , pada pasal 28 , ayat 3 , ialah kemampuan pendidik sebagai bagian dari masyarakat untuk berkomunikasi dan bergaul secara efektif dengan peserta didik, sesama pendidik, tenaga kependidikan, orang tua/wali peserta didik dan masyarakat sekitar.

Kompetensi sosial merupakan kemampuan berkomunikasi secara efektif dengan peserta didik, sesama pendidik/tenaga kependidikan lain, orang tua/wali peserta didik dan masyarakat sekitar. Sedangkan menurut Hamzah B. Uno kompetensi sosial artinya guru harus mampu menunjukkan dan berinteraksi sosial, baik dengan murid-muridnya maupun dengan sesama guru dan kepala sekolah, bahkan dengan masyarakat luas. (Sulfemi:2015)

\section{Kompetensi Profesional}

Guru profesional adalah guru yang memiliki kompetensi yang dipersyaratkan untuk melakukan tugas pendidikan dan pengajaran. Kompetensi di sini meliputi pengetahuan, sikap, dan keterampilan profesional, baik yang bersifat pribadi, sosial, maupun akademis. Kompetensi profesional merupakan salah satu kemampuan dasar yang harus dimiliki seseorang guru. Dalam Peraturan Pemerintah No 19 tahun 2005, pada pasal 28 ayat 3 yang dimaksud dengan kompetensi profesional adalah kemampuan penguasaan materi pembelajaran secara luas dan mendalam yang memungkinkannya membimbing peserta didik memenuhi standar kompetensi yang ditetapkan dalam Standar Nasional Pendidikan.

Adapun dalam kompetensi ini seorang guru hendaknya mampu untuk:

1) Menguasai materi, struktur, konsep dan pola pikir keilmuan yang mendukung mata pelajaran yang ditempuh.

2) Menguasai standar kompetensi dan kompetensi dasar mata pelejaran/bidang pengembangan yang ditempuh.

3) Mengembangkan materi pembelajaran yang diampu secara kreatif.

4) Mengembangkan keprofesionalan serta berkelanjutan dengan melakuan tindakan reflektif.

5) Memanfaatkan teknologi informasi dan komunikasi untuk berkomunikasi dan mengembangkan diri.

Dalam Peraturan Pemerintah tentang Standar Nasional Pendidikan (SNP) Nomor 19/2005 tidak secara eksplisit dinyatakan guru sebagai jabatan dan atau pekerjaan profesional. Di sini hanya disebutkan seorang guru sebagai agen pembelajaran diharuskan memiliki 
kompetensi profesional, di samping kompetensi lainnya: kompetensi pedagogik, kompetensi kepribadian, dan kompetensi sosial (Pasal 28 Ayat 3).

Bila menyimak dari isi PP 19/2005 ini, seharusnya kita akan menjadi lebih terang setelah membaca pasal-pasal tentang kualifikasi, kompetensi, sertifikasi, dan prinsip profesional calon guru atau guru. Namun, sayangnya, penggunaan istilah-istilah ini sedikit saja menolong, selebihnya justru mengacaukan pemahaman kita. Maka terdapat

beberapa hal yang perlu lebih dicermati bersama :

1. Poin penting dari PP SNP dalam perkara ini adalah menetapkan bahwa setiap pendidik di setiap jenjang pendidikan harus memiliki kualifikasi akademik minimum D4 atau sarjana (S1) pada bidang/program pendidikan yang sesuai dengan bidang yang diajarkan atau sesuai dengan jenjang tempat mengajar, dan harus pula memiliki sertifikat profesi guru (Pasal 29). Tetapi, uraian lebih lanjut tentang kualifikasi akademik dan kompetensi akan dikembangkan oleh Badan Standar Nasional Pendidikan (BSNP) dan ditetapkan dengan peraturan menteri.

2. Prinsip Profesional dalam Bab III Pasal 7 Ayat 1 sepertinya menjadi persyaratan administratif belaka. Ia tidak menunjukkan kemahiran apa yang menjadi ciri khas dan dasar untuk menilai guru dan dosen profesional jika dibandingkan dengan yang bukan profesional. Seharusnya sebuah prinsip adalah sesuatu yangatu (innate), tetap (immanent), dan menjadi basis untuk menjelaskan serta membedakan sesuatu fenomena yang sejenis. Sebagai contoh kita dapat dengan mudah membedakan fenomena seorang dokter dengan mantri atau dengan seorang dukun melalui cara kerjanya.

3. Selain memiliki ijazah S1 atau D4 dan memiliki sertifikat kompetensi, seseorang yang hendak menjadi guru harus juga memiliki sertifikat profesi. Sertifikat profesi adalah bukti formal sebagai pengakuan kewenangan bagi yang telah memiliki kualifikasi akademik minimal dan sertifikat kompetensi. Sertifikat ini dikeluarkan oleh perguruan tinggi yang memiliki program pengadaan tenaga kependidikan yang terakreditasi.

Dari tiga point ini kiranya perlu diperjelas lagi, apakah ini maksudnya satu paket dengan sertifikasi kompetensi, seperti yang dialami oleh lulusan lembaga kita selama ini sebagai lembaga penghasil tenaga kependidikan (LPTK), dimana ketika tamat sudah mengantongi dua ijazah sekaligus, ijazah S1 keguruan dan ijazah/akta IV. Karena kalau tidak diperjelas maka bubarlah Lembaga kita ini sebagai lembaga penghasil calon tenaga kependidikan ini.(Sulfemi:2015)

\subsection{PERAN PENDIDIK DAN TENAGA KEPENDIDIKAN}

Peran Tenaga Pendidik, yaitu :
A. Mampu menemukan pembawaan (bakat) peserta didiknya.
B. Mampu menolong peserta didiknya dalam perkembangannya.
C. Mampu menunjukkan jalan yang terbaik bagi perkembangan
peserta didiknya 
D. Mampu mengadakan evaluasi setiap waktu sebagai bentuk perhatian terhadap perkembangan peserta didiknya.

E. Mampu memberikan bimbingan dan penyuluhan terhadap peserta didik yang menghadapi kesulitan dalam proses pendidikannya.

F. Mampu memahami bakat bawaan para peserta didiknya danberusaha memberi jalan agar mereka mampu mengembangkan potensi dirinya melalui pendidikan itu sendiri.

G. Mampu dan pandai berinstropeksi diri.

H. Pendidik harus pandai memilih metode atau teknik pengajaran yang sesuai dengan materi pembelajaran dan peserta didiknya serta lingkungan sekitarnya.

Dalam Undang Undang No. 20 Tahun 2003 dan Undang Undang No. 14 Tahun 2005 juga dipaparkan peran/tugas guru adalah sebagai pendidik, pengajar, pembimbing, pengarah, pelatih, penilai dan pengevaluasi dari peserta didik.

1. Guru Sebagai Pendidik harus menjadi tokoh panutan dan identifikasi bagi para peserta didik dan lingkungannya. Oleh karena itu guru harus mempunyai standar kualitas pribadi tertentu, yang mencakup tanggungjawab, wibawa, mandiri dan disiplin.

2. Guru Sebagai Pengajar. Di dalam tugasnya, guru membantu peserta didik yang sedang berkembang untuk mempelajari sesuatu yang belum diketahuinya, membentuk kompetensi dan memahami materi standar yang dipelajari. Guru sebagai pengajar, harus terus mengikuti perkembangan teknologi, sehinga apa yang disampaikan kepada peserta didik merupakan hal-hal yang uptodate dan tidak ketinggalan jaman.

3. Guru Sebagai Pembimbing dapat dibaratkan sebagai pembimbing perjalanan yang berdasar-kan pengetahuan dan pengalamannya yang bertanggungjawab. Sebagai pembimbing, guru harus merumuskan tujuan secara jelas, menetapkan waktu perjalanan, menetapkan jalan yang harus ditempuh, menggunakan petunjuk perjalanan serta menilai kelancarannya sesuai dengan kebutuhan dan kemampuan peserta didik.

4. Guru Sebagai Pengarah harus mengarahkan bagi peserta didik, bahkan bagi orang tua. Sebagai pengarah guru harus mampu mengarahkan peserta didik dalam memecahkan permasalahan-permasalahan yang dihadapi, mengarahkan peserta didik dalam mengambil suatu keputusan dan menemukan jati dirinya.

5. Guru Sebagai Pelatih. Di dalam proses pendidikan dan pembelajaran memerlukan latihan ketrampilan, baik intelektual maupun motorik, sehingga menuntut guru untuk bertindak sebagai pelatih, yang bertugas melatih peserta didik dalam pembentukan kompetensi dasar sesuai dengan potensi masing-masing peserta didik. 
6. Guru Sebagai Penilai. Penilaian atau evalusi merupakan aspek pembelajaran yang paling kompleks, karena melibatkan banyak latar belakang dan hubungan, serta variabel lain yang mempunyai arti apabila berhubungan dengan konteks yang hampir tidak mungkin dapat dipisahkan dengan setiap segi penilaian. 


\section{BAB 3}

\section{PENUTUP}

\section{KESIMPULAN}

pengertian pendidik menurut istilah telah banyak dirumuskan oleh para ahli pendidikan, menurut Sutari Imam Barnadib pendidik adalah orang yang dengan sengaja mempengruhi orang lain untuk mencapai kedewasaan, lain halnya menurut Ahmad Tafsir menyatakan bahwa pendidik adalah siapa saja yang bertanggung jawab terhadap perkembangan peserta didik. Maka secara umum pendidik Ialah orang yang memikul pertanggung jawaban untuk mendidik, sedangkan secara khusus pendidik dalam perspektif islam adalah orang-orang yang bertanggung jawab terhadap perkembangan peserta didik, baik potensi kognitif, afektif maupun psikomotorik yang sesuai dengan nilai-nilai ajaran islam.

Tenaga Kependidikan adalah anggota masyarakat yang mengabdikan diri dan diangkat untuk menunjang Penyelenggaraan Pendidikan. Yang termasuk ke dalam tenaga kependidikan adalah: kepala satuan pendidikan; pendidik; dan tenaga kependidikan lainnya.

Kompetensi Pendidik dan Tenaga kependidikan adalah 1).Kompetensi Pedagogik 2).Kompetensi kepribadian, 3). Kompetensi sosial, 4). Kompetensi profesional. 


\section{DAFTAR PUSTAKA}

http://ithasartika91.blogspot.com/2011/02/pengertian-pendidik-dan-tenaga.html?m=1

Diakses Pada 26 November 2019 14:40WIB

http://asepsupriadijayanaga.gurusiana.id/article/arti-pendidik-678728 Diakses Pada 26 November 2019 17:00WIB

Sulfemi, Wahyu Bagja dan Lestari, Ayu Hopilatul. (2017). Korelasi Kompetensi Pedagogik Guru dengan Prestasi Belajar Mata Pelajaran IPS Di SMP Muhammadiyah Pamijahan Kabupaten Bogor. Edutecno. 16 (1), 1-16.

http://indahkumalla.blogspot.com/2014/12/peran-dan-fungsi-tenaga-pendidik.html?m=1 Diakses Pada 26 November 2019 19:00 WIB

Nur, H.(2009) Pendidik Dan Tenaga Kependidikan. Jurnal Medtek, 1

Permana, A. Y., \& Agus, S. MEMBANGUNAN PROFESIONALISME TENAGA KEPENDIDIKANMELALUI SERTIFIKASI: ANTARAHARAPANDAN REALITA.

Sulfemi, Wahyu Bagja. (2015). Kemampuan Pedagogik Guru. Prosiding Seminar Nasional. STKIP Muhammadiyah Bogor 1. (1). 71-83.

Sulfemi, Wahyu Bagja. (2015). Kemampuan Pedagogik Guru. Prosiding Seminar Nasional. STKIP Muhammadiyah Bogor 1. (1). 71-83.

Sulfemi, Wahyu Bagja. (2016). Perundang-Undangan Pendidikan. Bogor : Program Studi Administrasi Pendidikan STKIP Muhammadiyah Bogor.

Sulfemi, Wahyu Bagja dan Supriyadi, Dede. (2018). Pengaruh Kemampuan Pedagogik Guru dengan Hasil Belajar IPS. Edutecno 17 (1), 1-10. 


\section{SOAL}

1. Standar Pendidik dan tenaga kependidikan diatur dalam
A. Permen No. 12 Tahun 2006
B. Permen No. 12 Tahun 2007 *
C. Permen No. 12 Tahun 2008
D. Permen No. 12 Tahun 2009
E. Permen No. 12 Tahun 2010

2. siapa saja yang bertanggung jawab terhadap perkembangan peserta didik. Maka secara umum pendidik Ialah orang yang memikul pertanggung jawaban untuk mendidik. pernyataan Diatas merupakan definisi Pendidik yang di kemukakan oleh..
A. Jack strom
B. Ahmad Tafsir *
C. Ahmad Taszir
D. Mc. Donald
E. Semua Jawaban salah.

3. Tenaga Kependidikan telah lama dinyatakan dalam sebuah pasal...
A. Pasal 140 Ayat 1 (RPP, Bab XII/2005) *
B. Pasal 141 Ayat 1 (RPP, Bab XII/2005)
C. Pasal 140 Ayat 1 (RPP, Bab XII/2006)
D. Pasal 141 Ayat 1 (RPP, Bab XII/2006)
E. Pasal 140 Ayat 1 (RPP, Bab XI/2005)

4. Dalam UU Guru dan Dosen Pasal 2 Ayat 3 dijelaskan ada beberapa kompetensi guru yang meliputi..

A. kompetensi pedagogik, kompetensi kepribadian, kompetensi ekonomi, dan kompetensi professional 
B. kompetensi pedagogik, kompetensi kepribadian, kompetensi sosial, dan kompetensi professional *

C. kompetensi pedagogik, kompetensi kejiwaan, kompetensi sosial, dan kompetensi professional

D. kompetensi pedagogik, kompetensi kepribadian, kompetensi Ekonomi, dan kompetensi Masyarakat,

E. Semua jawaban salah.

5.kemampuan berkomunikasi secara efektif dengan peserta didik, sesama pendidik/tenaga kependidikan lain, orang tua/wali peserta didik dan masyarakat sekitar. Merupakan pengertian dari..
A. Kompetensi pribadi
B. Kompetensi ekonomi
C. Kompetensi sosial *
D. Kompetensi pedagogik
E. Kompetensi masyarakat

6. Dalam Undang Undang No. 20 Tahun 2003 dan Undang Undang No. 14 Tahun 2005 juga dipaparkan peran/tugas guru adalah sebagai..
A. Sebagai Penyemangat
B. Sebagai penentu
C. Sebagai pembimbing *
D. Sebagai Penolong
E. Semua jawaban salah

7.guru harus merumuskan tujuan secara jelas, menetapkan waktu perjalanan, menetapkan jalan yang harus ditempuh, menggunakan petunjuk perjalanan serta menilai kelancarannya sesuai dengan kebutuhan dan kemampuan peserta didik..

A. pendidik 

B. pengajar
C. pembimbing *
D. pengarah
E. penilai dan pengevaluasi dari peserta didik.

8. Apa yang di maksud kompetensi sosial menurut Hamzah B. Uno?
A. guru yang memiliki kompetensi yang dipersyaratkan untuk melakukan tugas pendidikan dan pengajaran.
B. kemampuan berkomunikasi secara efektif dengan peserta didik, sesama pendidik/tenaga kependidikan lain, orang tua/wali peserta didik dan masyarakat sekitar
C. guru harus mampu menunjukkan dan berinteraksi sosial, baik dengan murid- muridnya maupun dengan sesama guru dan kepala sekolah, bahkan dengan masyarakat luas. *
D. jawaban A dan B benar
E. Semua Jawaban salah.

9. Didalam Permen No. 12 Tahun 2007 yang mana mengatur tentang standar..
A. Standar sapras
B. Standar Pendidik dan tenaga kependidikan *
C. Standar sosial
D. Standar Kompetensi
E. Standar lulusan

10. Apa yang di maksud kompetensi pedagogik guru?
A. guru harus mampu menunjukkan dan berinteraksi sosial, baik dengan murid- muridnya maupun dengan sesama guru dan kepala sekolah, bahkan dengan masyarakat luas.
B. guru yang memiliki kompetensi yang dipersyaratkan untuk melakukan tugas pendidikan dan pengajaran


C. kemampuan berkomunikasi secara efektif dengan peserta didik, sesama pendidik/tenaga kependidikan lain, orang tua/wali peserta didik dan masyarakat sekitar

D. kemampuan dalam mengelola pembelajaran peserta didik, yang meliputi: a) pemahaman peserta didik, b) perancang dan pelaksanaan pembelajaran, c) evaluasi pembelajaran dan, d) pengembangan peserta didik untuk mengaktualisasi berbagai potensi yang dimilikinya.

E. Semua Jawaban Salah

\section{ESSAI}

1.Apa yang dimaksud dengan kompetensi sosial?

Jawaban.

kemampuan berkomunikasi secara efektif dengan peserta didik, sesama pendidik/tenaga kependidikan lain, orang tua/wali peserta didik dan masyarakat sekitar.

2.anggota masyarakat yang mengabdikan diri dan diangkat untuk menunjang Penyelenggaraan Pendidikan. Yang termasuk ke dalam tenaga kependidikan adalah: kepala satuan pendidikan; pendidik; dan tenaga kependidikan lainnya. Merupakan definisi dari..

Jawaban. Tenaga Kependidikan

3. Sebutkan regulasi yang menjelaskan tentang Standar Pendidik dan tenaga kependidikan Jawaban. Permen No. 12 Tahun 2007

4. Sebutkan kompetensi yang harus dimiliki oleh guru berdasarkan UU Guru dan Dosen Pasal 2 Ayat 3.

Jawaban. kompetensi pedagogik, kompetensi kepribadian, kompetensi sosial, dan kompetensi professional

5. Coba kemukakan definisi Kompetensi sosial menurut Hamzah B. Uno.

Jawaban.

guru harus mampu menunjukkan dan berinteraksi sosial, baik dengan murid-muridnya maupun dengan sesama guru dan kepala sekolah, bahkan dengan masyarakat luas. 